\title{
Price convergence in the UK supermarket chains: Evidence from nonlinear cointegration approach
}

\author{
Kai Yin Woo* • Shu Kam Lee \\ Department of Economics and Finance, Hong Kong Shue Yan University, North Point, Hong Kong SAR
}

Received: 30 March 2018

Revised: 01 October 2018

Accepted: 01 October 2018

\begin{abstract}
Supermarket chain is an important sector of the UK grocery stores and the growing dominance of supermarket chains has brought public concern over exploitation of market power in the UK retail grocery industry. This paper therefore aims to examine the price convergence of the UK supermarket products. Since the cointegrating relationship between supermarket prices may not be exact or linear, we adopt the rank tests for analysis which do not require prior knowledge and specification of the linear or nonlinear functional form. Our results confirm the evidence of the price convergence of all grocery products and then validate the price competition between the UK supermarket chains. Furthermore, a subset of the cointegration relationships exhibits nonlinear long-run price co-movements.
\end{abstract}

Keywords: rank tests; nonlinear cointegration; price convergence; relevant market JEL Classification Codes: C10, C13, C22

\section{Introduction}

The UK retail industry covers all businesses that sell goods to the public. According to the Institute of Grocery Distribution, the total sales value of the UK grocery retail market was estimated at about $£ 178$ billion in 2015 . Also, the shares of food and grocery expenditure over total UK retail spending increased from around 40\% in 2007 to $50 \%$ in 2016 (Verdict Research, 2008; Vasquez-Nicholson, 2016). Grocery retailing is therefore the largest retail business in the UK (Seaton and Waterson, 2013). Supermarket chain is an important sector of the UK grocery stores (Vasquez-Nicholson, 2016). The general public has expressed concern over the high concentration for supermarket chains as measured by, for example, the four-firm concentration ratio, which was estimated to be about $71 \%$ in the UK retail industry (Vasquez-Nicholson, 2016). Nevertheless, a high market share is necessary but not sufficient to possess and exploit market

\footnotetext{
*Corresponding author. E-mail: kywoo@hksyu.edu.

Citation: Woo, K. Y., and Lee, S. K. (2018) Price convergence in the UK supermarket chains: Evidence from nonlinear cointegration approach, Economics and Business Letters, 7(3), 115-125.
} 
power so that it may not necessarily result in anti-competitive behaviours. For instance, contestable market theory shows that markets with only a few producers do not restrain competition due to the existing threat of potential entrants. Thus, measuring market concentration may not be effective for assessing the competitive environment.

In competition policy research, the first step is to define the relevant market, which helps to evaluate the competitive conditions and calculate market shares in the defined market boundary for assessing market power. A relevant market constitutes the set of products or geographic areas that are substitutable and competing with each other, thus constraining the market power of the firms being analyzed. In the context of grocery retailing, if a shock raises the price of the products in one grocery store, consumers will likely switch to its close substitutes in another store. The resulting demand for the substitutes will rise and their prices will increase as a response. In other words, competitive forces tend to move the prices of closely related products together, and these prices eventually converge within the same relevant market in the long run. Research studies have adopted cointegration analysis for delineation of the relevant market. Evidence of product price cointegration reveals the existence of long-run price convergence and competition in the same relevant market (Woo et al., 2017). Otherwise, the products are sold in separate markets.

The high concentration of the supermarket chains has been a primary concern in the UK retail industry so that the UK Competition Commission has conducted two investigations through questionnaire, round-table discussions, industry surveys and so on to assess whether supermarket retailers were exercising market power along the supply chain (Competition Commission, 2000 and 2008). The purpose of this paper is to examine the convergence of supermarket prices using nonlinear cointegration analysis in order to detect if price competition between supermarket chains is evident in the UK retail industry and if the price co-movements are nonlinear in nature.

It is argued that the interrelationships between retailer prices can be characterised through price reaction functions, which were previously specified as a linear form (for example, Revoredo-Giha and Renwick, 2012) but there is no a prior reason to believe that they are necessarily of this form (Baumol et al., 1964). The price reaction functions may be nonlinear on the basis of different theoretical backgrounds with no single theory for any precision in the functional form. While parametric linear and nonlinear cointegration tests require the functional form to be exact for estimation, they would suffer from a misspecification problem if the wrong parametric models are identified, and therefore may not be appropriate for our study on competition analysis. On the other hand, the non-parametric rank tests proposed by Breitung (2001) have advantages over their parametric counterparts since they do not require such prior knowledge and precise specification of the linear or nonlinear functional form. In the literature, rank tests for nonlinear cointegration have been applied to validate for purchasing power parity (Haug and Basher, 2011; Chang and Su, 2013). Therefore, we suggest using the non-parametric rank tests for nonlinear cointegration as our methodology to study long-run price convergence and competition in the UK retail industry on a set of grocery categories.

The next section discusses the method of rank tests, followed by data description and interpretation of the empirical results, with the conclusion in the final section.

\section{Method}

Consider the general nonlinear functional relationship between two variables $\mathrm{y}_{\mathrm{t}}$ and $\mathrm{x}_{\mathrm{t}}$ given by:

$$
\mathrm{g}\left(\mathrm{y}_{\mathrm{t}}\right)=\mathrm{f}\left(\mathrm{x}_{\mathrm{t}}\right)+\mathrm{u}_{\mathrm{t}}
$$

where $g\left(y_{t}\right)$ and $f\left(x_{t}\right)$ are both $I(1)$ series, for $t=1, \ldots T$. The functions $g\left(y_{t}\right)$ and $f\left(x_{t}\right)$ are monotonically increasing but they are usually unknown in practice. If $u_{t}$ is $I(0)$, then a nonlinear 
cointegration relationship is said to exist between $y_{t}$ and $x_{t}$. While the sequence of ranks is invariant to a monotonic transformation of the original data, the rank transformation enables us to move away from the specific functional forms of the cointegration relationship. The rank test statistics are then constructed by replacing unknown $g\left(y_{t}\right)$ and $f\left(x_{t}\right)$ with the ranked series, which are defined as $R_{T}\left[g\left(y_{t}\right)\right]=R_{T}\left(y_{t}\right)$ and $R_{T}\left[f\left(x_{t}\right)\right]=R_{T}\left(x_{t}\right)$, for $R_{T}\left(w_{t}\right)=$ Rank of $\left[w_{t}\right.$ among $\left.\mathrm{w}_{1}, \ldots, \mathrm{w}_{\mathrm{T}}\right]$ where $\mathrm{w}=\{\mathrm{y}, \mathrm{x}\}$.

Breitung (2001) proposes two rank test statistics for cointegration based on distance measures between the sequences of ranked series:

$$
\begin{gathered}
\kappa^{*}=\frac{\sup _{1<t<\mathrm{T}}\left|\mathrm{d}_{\mathrm{t}}\right|}{\mathrm{T} \hat{\sigma}_{\Delta \mathrm{d}}} \\
\psi^{*}=\frac{\sum_{\mathrm{t}=1}^{\mathrm{T}} \mathrm{d}_{\mathrm{t}}^{2}}{\mathrm{~T}^{3} \hat{\sigma}_{\Delta \mathrm{d}}^{2}}
\end{gathered}
$$

where $d_{t}=R_{T}\left(y_{t}\right)-R_{T}\left(x_{t}\right)$. Note that

$$
\hat{\sigma}_{\Delta \mathrm{d}}^{2}=\mathrm{T}^{-2} \sum_{\mathrm{t}=1}^{\mathrm{T}}\left(\mathrm{d}_{\mathrm{t}}-\mathrm{d}_{\mathrm{t}-1}\right)^{2}
$$

is used to adjust for possible correlation between the series of interest in the cases where $g\left(y_{t}\right)$ and $\mathrm{f}\left(\mathrm{x}_{\mathrm{t}}\right)$ are correlated.

The above rank tests (2) and (3) are one-sided tests applicable for functions $g\left(y_{t}\right)$ and $f\left(x_{t}\right)$ that are known to be monotonically increasing. When it is not certain whether these functions are monotonically increasing or decreasing, it is useful to apply a two-sided test constructed by Breitung (2001) using the least squares residuals which is obtained from a regression of $R_{T}\left(y_{t}\right)$ on $\mathrm{R}_{\mathrm{T}}\left(\mathrm{x}_{\mathrm{t}}\right)$ :

$$
\Phi(\mathrm{k})=\mathrm{T}^{-3} \hat{\sigma}_{\Delta \tilde{\mathrm{u}}}^{2} \sum_{\mathrm{t}=1}^{\mathrm{T}}\left(\tilde{\mathrm{u}}_{\mathrm{t}}^{\mathrm{R}}\right)^{2}
$$

where $\mathrm{k}$ is the number of regressors,

$$
\tilde{u}_{t}^{R}=R_{T}\left(y_{t}\right)-b_{T} R_{T}\left(x_{t}\right)
$$

is the least square residuals, where $\mathrm{b}_{\mathrm{T}}$ is the least squares estimate, and

$$
\hat{\sigma}_{\Delta \widetilde{u}}^{2}=\mathrm{T}^{-2} \sum_{\mathrm{t}=1}^{\mathrm{T}}\left(\widetilde{\mathrm{u}}_{\mathrm{t}}^{\mathrm{R}}-\widetilde{\mathrm{u}}_{\mathrm{t}-1}^{\mathrm{R}}\right)^{2}
$$

is used to account for a possible correlation among the series.

The sequences of the ranked series evolve similarly under cointegration; otherwise, they will diverge. Hence, the null hypothesis of no (nonlinear) cointegration between $y_{t}$ and $x_{t}$ is rejected if the above test statistics are smaller than their respective critical values.

When the rank test for cointegration indicates a stable long-run relationship, we proceed to testing whether the cointegrating relationship is linear or nonlinear. Under the null hypothesis of linear cointegration, the following dynamic OLS regression of $y_{t}$ on $x_{t}$ is obtained due to Stock and Watson (1993) in order to adjust for serial correlated errors and endogenous regressors:

$$
\mathrm{y}_{\mathrm{t}}=\gamma_{0}+\sum_{\mathrm{j}=1}^{\mathrm{p}} \alpha_{\mathrm{j}} \mathrm{y}_{\mathrm{t}-\mathrm{j}}+\gamma_{1} \mathrm{x}_{\mathrm{t}}+\sum_{\mathrm{j}=-\mathrm{q}}^{\mathrm{q}} \pi_{\mathrm{j}} \Delta \mathrm{x}_{\mathrm{t}-\mathrm{j}}+\mathrm{e}_{\mathrm{t}}
$$

Breitung (2001) suggests a rank test for neglected nonlinearity, which is a score statistic obtained as $\mathrm{TR}^{2}$ for the regression of the estimated residuals on the regressors of (5) and $\mathrm{R}_{\mathrm{T}}\left(\mathrm{x}_{\mathrm{t}}\right)$ given by: 


$$
\tilde{\mathrm{e}}_{\mathrm{t}}=\mathrm{a}_{0}+\sum_{\mathrm{j}=1}^{\mathrm{p}} \mathrm{a}_{\mathrm{j}} \mathrm{y}_{\mathrm{t}-\mathrm{j}}+\mathrm{b}_{1} \mathrm{x}_{\mathrm{t}}+\sum_{\mathrm{j}=-\mathrm{q}}^{\mathrm{q}} \mathrm{c}_{\mathrm{j}} \Delta \mathrm{x}_{\mathrm{t}-\mathrm{j}}+\theta \mathrm{R}_{\mathrm{T}}\left(\mathrm{x}_{\mathrm{t}}\right)+\varepsilon_{\mathrm{t}}
$$

where $\mathrm{R}^{2}$ is the coefficient of determination of regression (6), $\mathrm{p}$ and $\mathrm{q}$ are the finite lag orders. The null hypothesis of linear cointegration (i.e. $\theta=0$ ) is rejected in favour of nonlinear cointegration if $\mathrm{TR}^{2}$ exceeds the $\chi^{2}$ critical value with one degree of freedom.

Figure 1. Price indices of fourteen grocery categories across five supermarket chains.
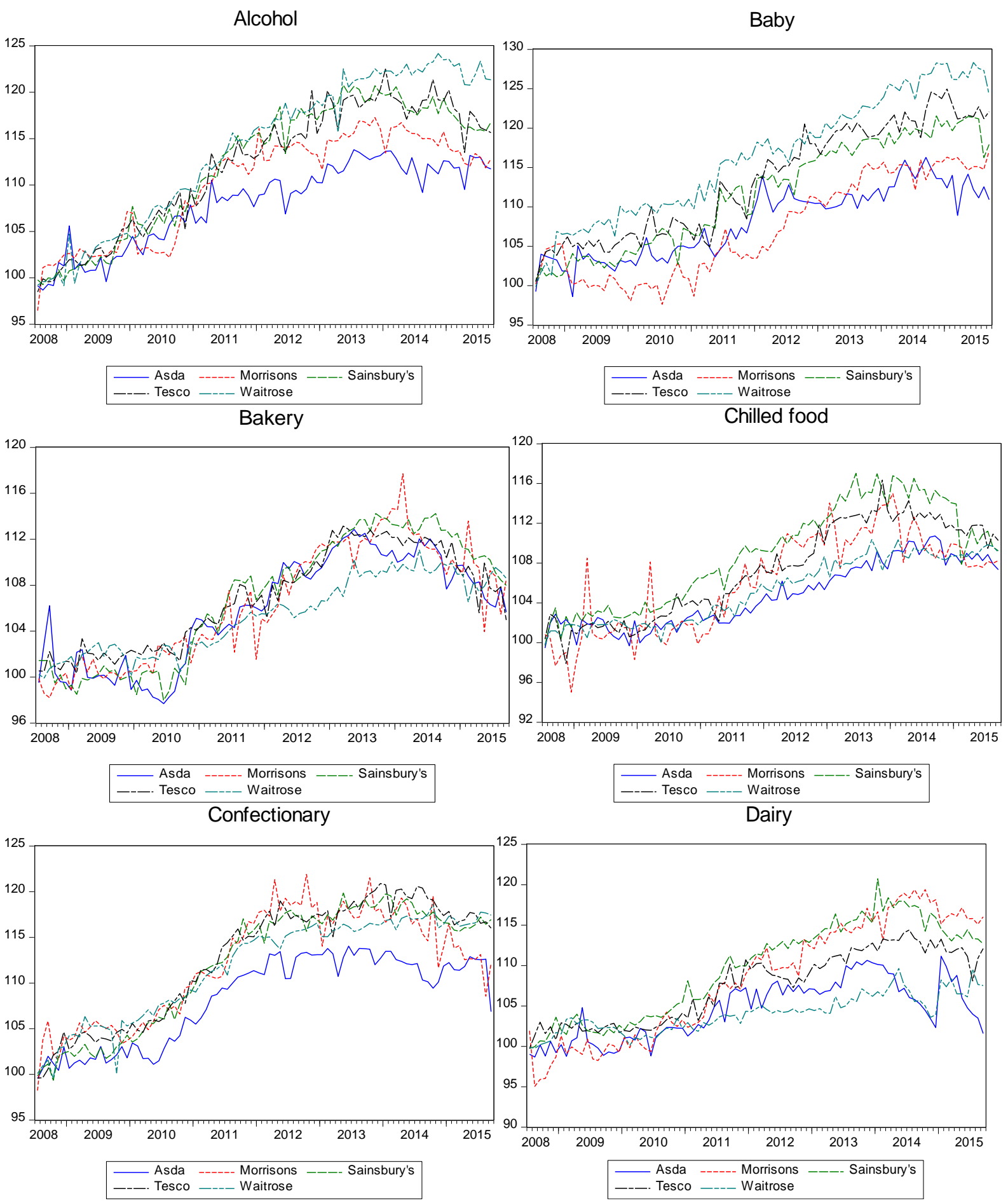


\section{Data and empirical results}

The data are collected from The Grocer (www.thegrocer.co.uk), a British magazine devoted to surveying grocery sales and prices ${ }^{1}$. They include monthly price indices of fourteen grocery categories (alcohol; baby; bakery; confectionery; chilled food; dairy; deli; dry grocery; frozen food; fruit \& vegetables; health \& beauty; household products and soft drinks) which are sold in five UK supermarket chains: Asda, Morrisons, Sainsbury's, Waitrose and Tesco with significant market shares in the UK supermarket industry (Vasquez-Nicholson, 2016; Lan \& Dobson, 2017). Unlike the previous studies on UK supermarkets such as Seaton and Waterson (2013) and Chakraborty et al. (2015), the price data in this study are category indexed averages rather than individual item levels, and also at monthly rather than weekly intervals. Hence, our study can avoid selectivity bias from each product category (Lloyd, 2008) and detect the price convergence in the long run, unaffected by the short-run pricing strategies. These price indices are seasonally adjusted using the X12 method. The sample period runs from 2008:07 to 2015:09, with 87 observations in total. Figure 1 depicts the movements of the price index series under study during the sample period. As shown, the price indices generally trended upward and reached the peak at around the mid of 2013, followed by a slight retreat. Graphically, they exhibit strong co-movements and move in the same direction in each category ${ }^{2}$.
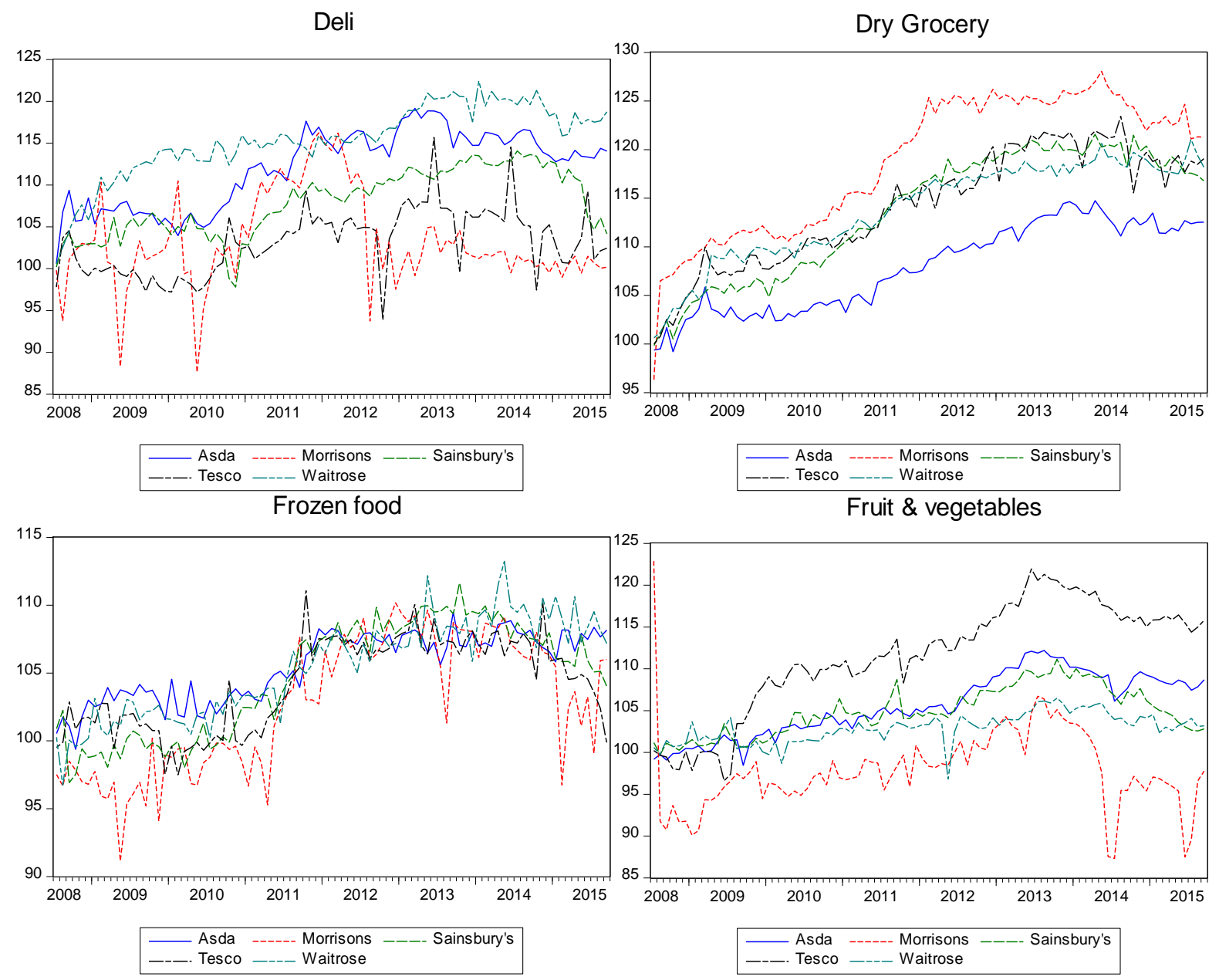

\footnotetext{
${ }^{1}$ Data carried by The Grocer is provided by BrandView. There is more information about the data available on the website of BrandView (www.brandview.com). Also, the data uses posted, rather than transaction, prices. Some literatures such as Chakraborty et al. (2015) and Lan \& Dobson (2017) adopted posted prices for analysis of pricing behaviours in the UK supermarkets.

${ }^{2}$ If the data move in different directions, the rank cointegration tests of Breitung (2001) cannot be used (Liew et al., 2012).
} 
Before undertaking the cointegration tests, existence of a unit root in the price index series is first verified. For the unit root and cointegration tests, all the price data are transformed into natural logarithms. The augmented Dickey-Fuller (ADF) unit root test is implemented in the ADF regression with a constant and a linear trend. As observed from the results in Table 1, the null of a unit root for the price indices in level cannot be rejected, but the null can be rejected for the price indices in first difference. Consequently, all data series are integrated of order one.

After the unit root test, the next step is to detect the existence of cointegration. Tesco, the largest supermarket chain in the UK in terms of market sales is selected as a base for cointegration analysis. Our study is then undertaken in the bivariate models of the price index of a grocery sold in one supermarket $\left(\mathrm{y}_{\mathrm{t}}\right)$ and the price index of the same category in Tesco $\left(\mathrm{x}_{\mathrm{t}}\right)$. In Table 2, we report the results of the rank tests for cointegration, together with the parametric EngleGranger (1987) cointegration $\tau$-test and z-test statistics for comparison, which are the DickeyFuller type of tests. The $\tau$-test and z-test statistics cannot reject the null hypothesis of noncointegration in most cases. Nevertheless, the null of non-cointegration can be rejected by at least a one-sided or two-sided rank test for all cases, which are based on our simulated smallsample critical values. From the simulation experiments in Breitung (2001), the non-parametric rank tests may outperform the parametric Dickey-Fuller type of tests under linear and nonlinear cointegration processes. Hence, the findings indicate absolutely strong evidence of price convergence and competition for grocery products in the UK retail industry and conclude that all products are in the same relevant markets. We then proceed with the score tests of nonlinearity, which as reported in Table 3 reject the null hypothesis of linear cointegration for some cases, especially in the category of bakery, confectionery and fruit \& vegetables, where some
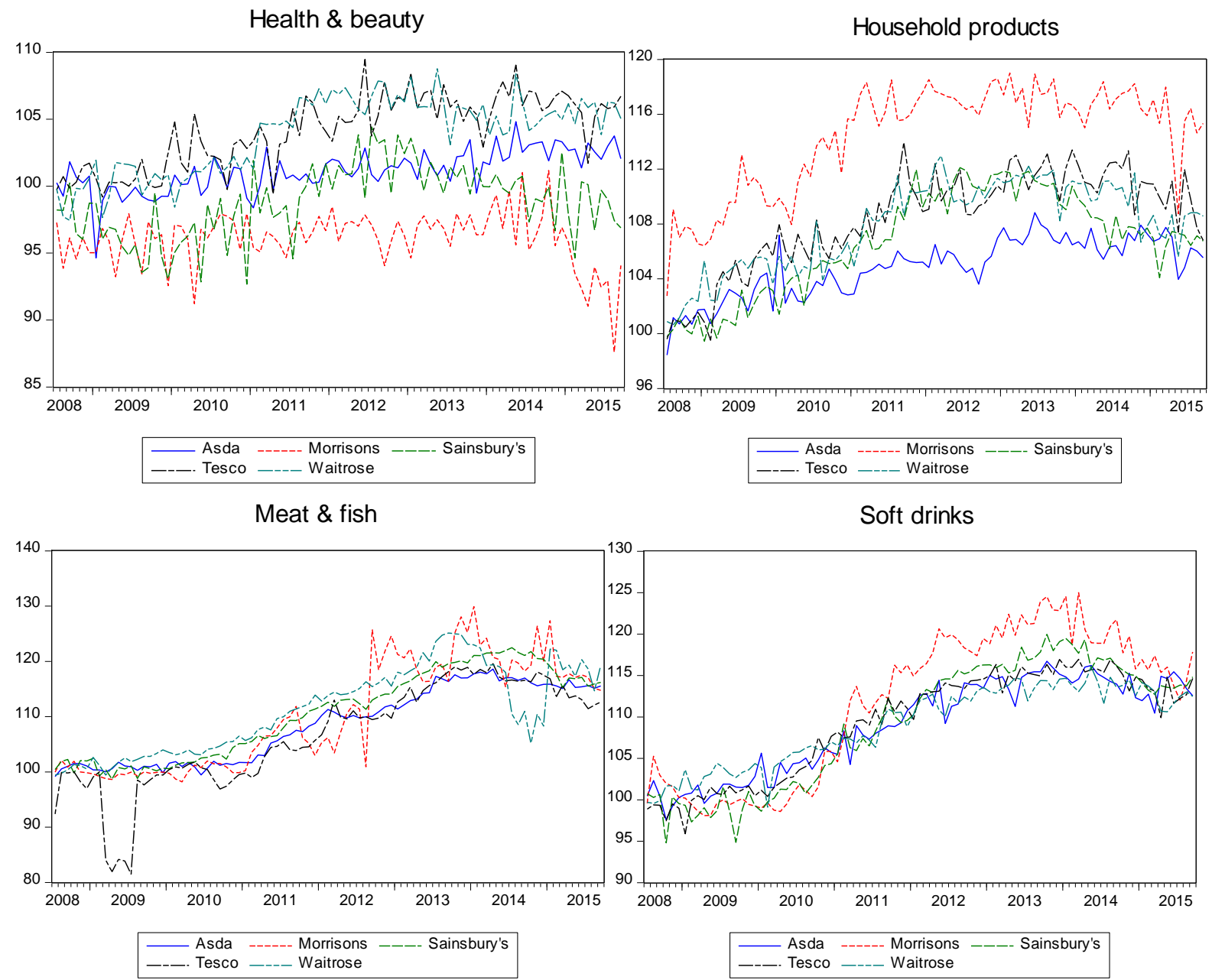
evidence of nonlinear long-run price co-movements of these groceries within the UK retail industry is found. The nonlinear cointegration relationship between prices that are in the form of discontinuous or nonlinear price reaction functions may be caused by various theoretical reasons such as nonlinear demand functions (Maskin \& Tirole, 1988; Cowan, 2007), spatial product differentiation (Tabuchi \& Thisse, 1995; Martin, 2002; Scrimitore, 2003) and game-theoretical strategic behaviours (Dhar et al. 2005; Xu \& Hajek, 2013). Empirically, existence of transportation costs and measurement errors in data (Taylor, 1988), and asymmetric price competition dynamics (Woo et al., 2017) may also lead to the rejection of linear cointegration relationship between retailer prices.

Table 1. ADF unit root tests.

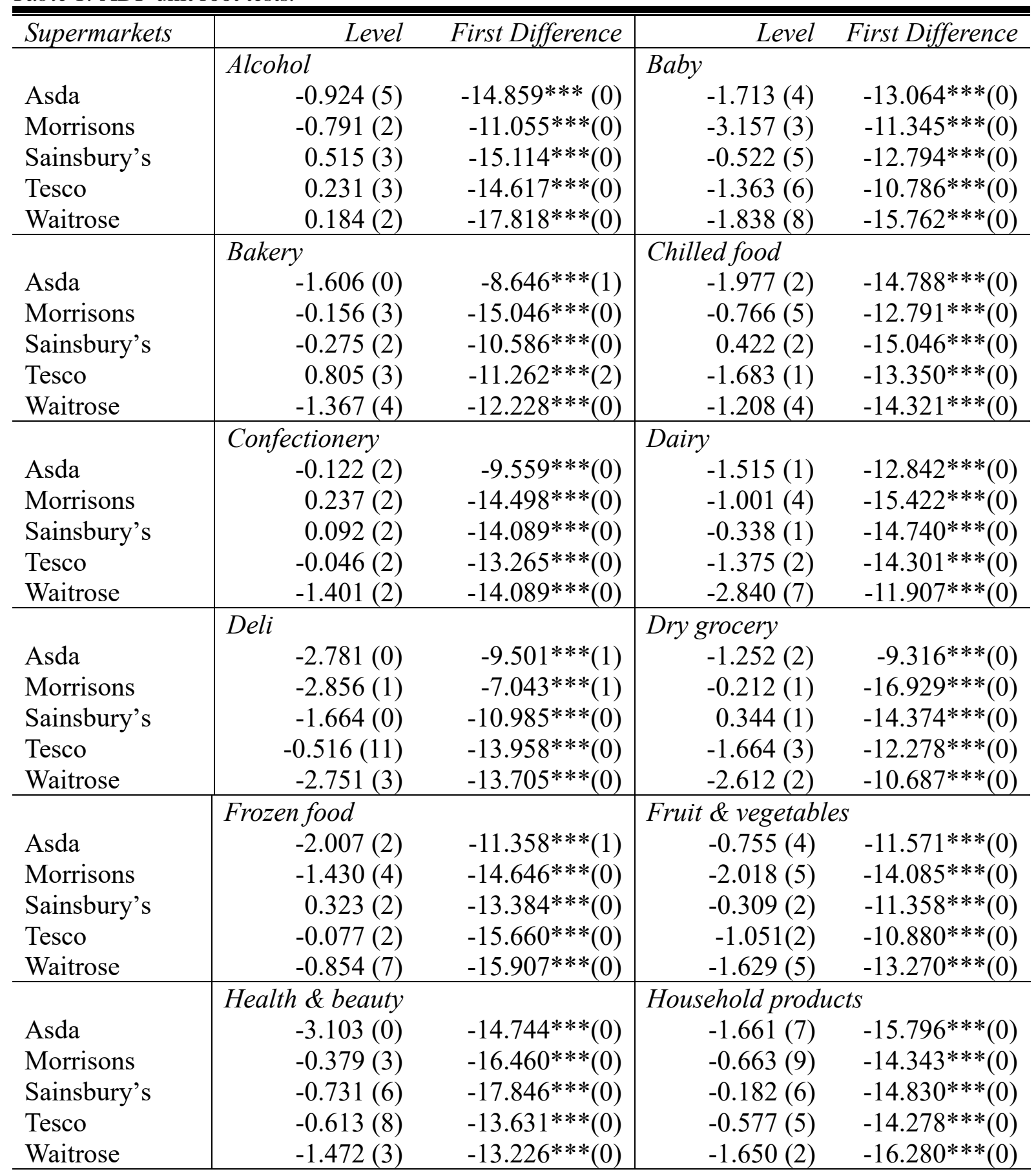




\begin{tabular}{|c|c|c|c|c|}
\hline & Meat \& fish & & Soft drinks & \\
\hline Asda & $-1.116(1)$ & $-11.041 * * *(0)$ & $-0.070(5)$ & $-14.625 * * *(0)$ \\
\hline Morrisons & $-2.260(1)$ & $-15.160 * * *(0)$ & $-1.110(1)$ & $-12.750 * * *(0)$ \\
\hline Sainsbury’s & $-1.014(0)$ & $-12.683 * * *(0)$ & $-0.678(2)$ & $-12.333 * * *(0)$ \\
\hline Tesco & $-3.026(0)$ & $-10.0257 * * *(0)$ & $-0.052(2)$ & $-16.557 * * *(0)$ \\
\hline Waitrose & $-1.923(1)$ & $-3.468 * *(4)$ & $0.011(4)$ & $-12.145 * * *(0)$ \\
\hline
\end{tabular}

Notes: A constant and a linear trend are included in the ADF regression; The critical values are $-3.159,-3.466$ and -4.075 for the 10\%, 5\% and 1\% significance level, respectively; The figures in the parentheses are the chosen lag lengths in the ADF regression. The lag lengths are selected to ensure the regression residuals to be white-noise processes; *, **, *** denote statistical significance at the $10 \%, 5 \%$ and $1 \%$ level, respectively.

Table 2. Cointegration tests.

Engle-Granger tests $\quad$ One-sided rank tests $\quad \begin{array}{r}\text { Two-sided } \\ \text { rank test }\end{array}$

\begin{tabular}{|c|c|c|c|c|c|}
\hline Supermarkets & $\tau$ & $z$ & $\kappa^{*}$ & $\psi^{*}$ & $\Phi(1)$ \\
\hline \multicolumn{6}{|l|}{ Alcohol } \\
\hline Asda & $-3.203^{*}$ & $-26.478 * * *$ & $0.2976^{* * *}$ & $0.0086^{* * *}$ & $0.0088 * * *$ \\
\hline Morrisons & -3.049 & $-25.413 * *$ & $0.3136^{* * *}$ & $0.0082 * * *$ & $0.0084 * * *$ \\
\hline Sainsbury's & -1.077 & -3.565 & $0.2834 * * *$ & $0.0064 * * *$ & $0.0065^{* * *}$ \\
\hline Waitrose & -0.030 & -0.130 & $0.3077 * * *$ & $0.0080 * * *$ & $0.0082 * * *$ \\
\hline \multicolumn{6}{|l|}{ Baby } \\
\hline Asda & $-3.445 * *$ & $-37.644 * * *$ & $0.2868 * * *$ & $0.0098 * *$ & $0.0099 * * *$ \\
\hline Morrisons & $-3.320^{*}$ & $-21.970 * *$ & $0.3489 * *$ & $0.0128 * * *$ & $0.0131 * * *$ \\
\hline Sainsbury's & -1.759 & -8.174 & $0.2511 * * *$ & $0.0072 * * *$ & $0.0073^{* * *}$ \\
\hline Waitrose & $-3.571 * *$ & $-20.538 * *$ & $0.2719 * * *$ & $0.0061 * * *$ & $0.0062 * * *$ \\
\hline \multicolumn{6}{|l|}{ Bakery } \\
\hline Asda & $-4.055 * * *$ & $-29.606^{* * *}$ & $0.2755^{* * *}$ & $0.0109 * * *$ & $0.0112 * * *$ \\
\hline Morrisons & $-3.885 * *$ & $-38.304 * * *$ & $0.2285 * * *$ & $0.0069 * * *$ & $0.0070 * * *$ \\
\hline Sainsbury's & -1.927 & -11.185 & $0.2629 * * *$ & $0.0093 * * *$ & $0.0095 * * *$ \\
\hline Waitrose & -0.625 & -2.975 & $0.3219^{*}$ & $0.0128 * * *$ & $0.0131 * * *$ \\
\hline \multicolumn{6}{|l|}{ Chilled food } \\
\hline Asda & -2.275 & -12.783 & $0.2555^{* * *}$ & $0.0096^{* * *}$ & $0.0098 * * *$ \\
\hline Morrisons & -2.848 & $-22.931 * *$ & $0.2794 * * *$ & $0.0096 * * *$ & $0.0097 * * *$ \\
\hline Sainsbury's & -2.771 & $-21.913 * *$ & $0.2015^{* * *}$ & $0.0055^{* * *}$ & $0.0056^{* * *}$ \\
\hline Waitrose & -1.933 & -14.761 & $0.2843 * * *$ & $0.0113 * * *$ & $0.0115^{* * *}$ \\
\hline \multicolumn{6}{|l|}{ Confectionery } \\
\hline Asda & -2.539 & $-18.859 *$ & $0.3268 * *$ & $0.0131 * * *$ & $0.0134 * * *$ \\
\hline Morrisons & -0.659 & -2.678 & $0.3053 * * *$ & $0.0114 * * *$ & $0.0116^{* * *}$ \\
\hline Sainsbury's & -1.791 & -10.493 & $0.2636 * * *$ & $0.0062 * * *$ & $0.0063 * * *$ \\
\hline Waitrose & -1.115 & -12.236 & $0.3401 * *$ & $0.0120 * * *$ & $0.0124 * * *$ \\
\hline \multicolumn{6}{|l|}{ Dairy } \\
\hline Asda & -2.766 & $-23.582 * *$ & $0.3775^{*}$ & $0.0157 * * *$ & $0.0160 * * *$ \\
\hline Morrisons & -2.934 & $-21.805^{* *}$ & $0.2534 * *$ & $0.0063 * * *$ & $0.0064 * * *$ \\
\hline Sainsbury's & $-3.461 * *$ & $-26.131 * * *$ & $0.2256^{* * *}$ & $0.0073 * * *$ & $0.0075^{* * *}$ \\
\hline Waitrose & -2.892 & $-31.646 * * *$ & $0.3472 * *$ & $0.0098 * * *$ & $0.0100 * * *$ \\
\hline \multicolumn{6}{|l|}{ Deli } \\
\hline Asda & -1.601 & -5.490 & $0.3080 * * *$ & $0.0067 * * *$ & $0.0072 * * *$ \\
\hline Morrisons & -2.396 & -14.243 & $0.2820 * * *$ & $0.0147 * * *$ & $0.0155^{* * *}$ \\
\hline Sainsbury's & -2.528 & -13.064 & $0.3897 *$ & $0.0134 * * *$ & $0.0152 * * *$ \\
\hline Waitrose & -3.002 & -11.161 & $0.3847^{*}$ & $0.0115^{* * *}$ & $0.0128 * * *$ \\
\hline
\end{tabular}




\begin{tabular}{|c|c|c|c|c|c|}
\hline \multicolumn{6}{|l|}{ Dry grocery } \\
\hline Asda & -1.978 & -10.019 & $0.2935 * * *$ & $0.0073 * * *$ & $0.0075^{* * *}$ \\
\hline Morrisons & -2.184 & -11.942 & $0.2990 * * *$ & $0.0116^{* * *}$ & $0.0119^{* * *}$ \\
\hline Sainsbury's & -2.153 & -12.705 & 0.4127 & $0.0059 * * *$ & $0.0061 * * *$ \\
\hline Waitrose & -2.553 & $-19.201 * *$ & $0.3697 *$ & $0.0088 * * *$ & $0.0090^{* * *}$ \\
\hline \multicolumn{6}{|l|}{ Frozen food } \\
\hline Asda & -1.715 & -11.600 & $0.3841 *$ & $0.0106 * * *$ & $0.0111 * * *$ \\
\hline Morrisons & -2.162 & -15.244 & $0.2036^{* * *}$ & $0.0069 * * *$ & $0.0072 * * *$ \\
\hline Sainsbury's & -2.504 & -15.087 & $0.2004 * * *$ & $0.0074 * * *$ & $0.0078 * * *$ \\
\hline Waitrose & -0.622 & -2.031 & $0.3002 * * *$ & $0.0127 * * *$ & $0.0134 * * *$ \\
\hline \multicolumn{6}{|c|}{ Fruit \& vegetables } \\
\hline Asda & -2.071 & -10.807 & $0.3009 * * *$ & $0.0082 * * *$ & $0.0083 * * *$ \\
\hline Morrisons & -2.293 & $-17.698 *$ & 0.4532 & $0.0217 * *$ & $0.0212 * *$ \\
\hline Sainsbury's & -2.033 & -13.221 & 0.4494 & $0.0206^{* *}$ & $0.0207 * *$ \\
\hline Waitrose & -2.469 & $-17.059 *$ & $0.3895^{*}$ & $0.0092 * * *$ & $0.0091 * * *$ \\
\hline \multicolumn{6}{|c|}{ Health \& beauty } \\
\hline Asda & -0.611 & -1.808 & $0.3167 * *$ & $0.0096^{* * *}$ & $0.0106^{* * *}$ \\
\hline Morrisons & -0.591 & -2.758 & $0.1945^{* * *}$ & $0.0087 * * *$ & $0.0089 * * *$ \\
\hline Sainsbury's & -1.412 & -5.527 & $0.1938^{* * *}$ & $0.0072 * * *$ & $0.0074 * * *$ \\
\hline Waitrose & -1.858 & -9.707 & $0.2079 * * *$ & $0.0083 * * *$ & $0.0089 * * *$ \\
\hline \multicolumn{6}{|c|}{ Household products } \\
\hline Asda & 1.481 & -8.208 & $0.2541 * * *$ & $0.0080 * * *$ & $0.0083^{* * *}$ \\
\hline Morrisons & -2.071 & $-17.626^{*}$ & $0.2288 * * *$ & $0.0081 * * *$ & $0.0084 * * *$ \\
\hline Sainsbury's & -1.655 & -6.551 & $0.2866^{* * *}$ & $0.0104 * * *$ & $0.0110^{* * *}$ \\
\hline Waitrose & -1.399 & -5.640 & $0.2392 * * *$ & $0.0065^{* * *}$ & $0.0068 * * *$ \\
\hline \multicolumn{6}{|l|}{ Meat \& fish } \\
\hline Asda & -2.704 & $-30.794 * * *$ & $0.3055^{* * *}$ & $0.0100 * * *$ & $0.0102 * * *$ \\
\hline Morrisons & $-3.402 *$ & $-23.641 * *$ & $0.3229 * *$ & $0.0107 * * *$ & $0.0109 * * *$ \\
\hline Sainsbury's & -1.888 & -10.374 & $0.2583 * * *$ & $0.0105 * * *$ & $0.0108^{* * *}$ \\
\hline Waitrose & $-3.276^{*}$ & $-20.400 * *$ & 0.4972 & $0.0252 *$ & $0.0258 *$ \\
\hline \multicolumn{6}{|l|}{ Soft drinks } \\
\hline Asda & -1.736 & $-17.992 *$ & $0.2822 * * *$ & $0.0065 * * *$ & $0.0067^{* * *}$ \\
\hline Morrisons & -2.729 & -14.914 & $0.2412 * * *$ & $0.0104 * * *$ & $0.0106^{* * *}$ \\
\hline Sainsbury's & -2.871 & $-16.184^{*}$ & $0.2308^{* * *}$ & $0.0057 * * *$ & $0.0058^{* * *}$ \\
\hline Waitrose & -2.976 & $-33.866^{* * *}$ & $0.2182 * * *$ & $0.0058 * * *$ & $0.0059 * * *$ \\
\hline
\end{tabular}

Notes: Modified Schwarz criterion is used to determine the number of lags in the Engle-Granger (1987) test regression; The significance of the Engle-Granger test statistics are based on Mackinnon's (1996) p-values; One regressor is included in the $\Phi(1)$ rank test; The small-sample critical values for the one-sided and two-sided cointegration rank tests were calculated by Monte Carlo simulations based on 50,000 replications for a sample size of 87 . They are mostly larger than the asymptotic counterparts as shown in Breitung (2001); The small-sample critical values are: $\kappa^{*}: * 10 \% 0.4003$, $* * 5 \% 0.3686, * * * 1 \% 0.3157 ; \psi^{*}: * 10 \% 0.0274, * * 5 \% 0.0226, * * * 1 \% 0.0162 ; \Phi(1): * 10 \% 0.0292, * * 5 \% 0.0238$, $* * * 1 \% 0.0168$.

\section{Conclusion}

This paper examines the price convergence of fourteen grocery categories between Tesco and other four UK supermarkets using nonlinear, non-parametric cointegration rank tests over the period from 2008:07 to 2015:09. The results confirm that the price indices move in the same direction and converge in the long run in the UK retail industry. Also, we find some evidence of nonlinear cointegration relationships between retail prices, providing motivation of further investigation into theoretical reasons for nonlinearity. 
Table 3. Score test of nonlinearity.

\begin{tabular}{l|r|r|r|r}
\hline \hline Supermarkets & Alcohol & Baby & Bakery & Chilled food \\
Asda & 0.4318 & 0.0891 & $4.5633^{* *}$ & 0.3946 \\
Morrisons & 1.4952 & 2.4051 & 0.3553 & 0.1439 \\
Sainsbury's & $7.0268^{* * *}$ & 0.9721 & $5.1012^{* *}$ & $2.852^{*}$ \\
Waitrose & 0.0445 & 0.2528 & $4.7622^{* *}$ & 0.7881 \\
\hline Supermarkets & Confectionery & Dairy & Deli & Dry grocery \\
Asda & $9.0603^{* * *}$ & 0.1075 & 0.4270 & 0.4728 \\
Morrisons & 0.9304 & 0.3853 & 0.0110 & 0.9975 \\
Sainsbury's & $2.8930^{*}$ & 0.3338 & 0.2329 & $5.2373^{* *}$ \\
Waitrose & $3.2077^{*}$ & 1.5773 & 0.0065 & 1.5708 \\
\hline Supermarkets & Frozen food & Fruit \& & Health \& & Household \\
Asda & 0.0067 & vegetables & beauty & products \\
Morrisons & 1.0378 & $0.1927^{* * *}$ & 0.0567 & 0.1673 \\
Sainsbury's & 0.4484 & $3.9056^{* *}$ & 1.0822 & 1.4744 \\
Waitrose & 0.9147 & $13.7113^{* * *}$ & $4.2711^{* *}$ & 0.1273 \\
\hline Supermarkets & Meat \& fish & Soft drinks & & 0.2298 \\
Asda & 1.8564 & 0.0986 & & \\
Morrisons & 1.9357 & 0.0838 & & \\
Sainsbury’s & 0.0019 & 1.9213 & & \\
Waitrose & 0.4756 & $3.5151^{*}$ & & \\
\hline \hline
\end{tabular}

Note: The critical values of the chi-squared distribution with one degree of freedom are 2.706, 3.841 and 6.636, at the $10 \%, 5 \%$ and $1 \%$ significance level.

\section{Acknowledgements}

The research of this paper is funded by the University Grants Committee (UGC) of the Hong Kong Special Administrative Region under the Faculty Development Scheme (FDS) (Project No. UGC/FDS15/B06/14). However, the views expressed in this paper are solely those of the authors and should not be attributed to the UGC.

\section{References}

Baumol, W. J., Quandt, R. E., and Sharpiro, H. T. (1964) Oligopoly theory and retail food pricing, Journal of Business, 37, 346-363.

Breitung, J. (2001) Rank tests for nonlinear cointegration, Journal of Business and Economic Statistics, 19, 331-340.

Chakraborty, R., Dobson, P. W., Seaton, J. S., and Waterson, M. (2015) Pricing in inflationary times: The penny drops, Journal of Monetary Economics, 76, 71-86.

Chang, T. Y., and Su, C. W. (2013) Revisiting purchasing power parity for East Asian countries using the rank test for nonlinear cointegration, Applied Economics, 45, 2847-2852.

Competition Commission (2000) Supermarkets; A report on the supply of groceries from multiple stores in the United Kingdom, UK: Competition Commission.

Competition Commission (2008) The supply of groceries in the UK market Investigation. UK: Competition Commission. Available from: http://www.ias.org.uk/uploads/pdf/Price\%20do cs/538.pdf

Cowan, S. (2007) The welfare effects of third-degree price discrimination with nonlinear demand functions, RAND Journal of Economics, 38, 419-428.

Dhar, T., Chavas, J. P., Cotterill, R. W., and Gould, B. W. (2005) An econometric analysis of 
brand-level strategic pricing between Coca-Cola Company and PepsiCo, Journal of Economic and Management Strategy, 14, 905-931.

Engle, R. F., and Granger, C.W.J. (1987) Co-Integration and error correction: representation, estimation and testing, Econometrica, 55, 251-276.

Haug, A. A., and Basher, S. A. (2011) Linear or nonlinear integration in the purchasing power parity?, Applied Economics, 43, 185-96.

Lan, H., and Dobson P. W. (2017) Healthy competition to support healthy eating? An investigation of fruit and vegetable pricing in UK Supermarkets, Journal of Agricultural Economics, 68, 881-900.

Liew, K. S., Ling, T.H, Chia, C. J., and Yoon G. (2012) On the application of the rank tests for nonlinear cointegration to PPP: The case of Papua New Guinea, Economic Modelling, 29, 326-332.

Lloyd, T. (2008) Price leadership in UK food retailing: Time series representation and evidence. Paper presented at the 82nd Annual Conference of the Agricultural Economics Society, Cirencester, UK.

Mackinnon, J. G. (1996) Numerical distribution functions for unit root and cointegration tests, Journal of Applied Econometrics, 11, 601-618.

Maskin, E., and Tirole, J. (1988) A theory of dynamic oligopoly, II: Price competition, kinked demand curves and Edgeworth cycles, Econometrica, 56, 571-599.

Martin, S. (2002) Advanced industrial economics, Oxford: Blackwell.

Revoredo-Giha, C., and Renwick, A. (2012) Retailers price behavior in the UK fresh fruit and vegetable market, Agribusiness, 28, 451-468.

Scrimitore, M. (2003) Symmetric and asymmetric equilibria in a spatial duopoly, 43rd Congress of the European Regional Science Association: "Peripheries, Centres, and Spatial Development in the New Europe", 27th - 30th August 2003, Jyväskylä, Finland, European Regional Science Association (ERSA), Louvain-la-Neuve.

Seaton, J. S., and Waterson, M. (2013) Identifying and characterizing price leadership in British supermarkets, International Journal of Industrial Organization, 31, 392-403.

Stock, J. H., and Watson, M. W. (1993) A simple estimator of cointegrating vectors in higher order integrated systems, Econometrica, 61, 783-820.

Tabuchi, T., and Thisse, J. F. (1995) Asymmetric equilibria in spatial competition, International Journal of Industrial Organization, 13, 213-227.

Taylor, M. (1988) An empirical examination of long-run purchasing power parity using cointegration techniques, Applied Economics, 20, 1369-1381.

Vasquez-Nicholson, J. (2016) Retail Foods, USDA'S Global Agriculture Information Network (GAIN).

Verdict Research (2008) Food and Grocery 2008.

Woo, K. Y., Lee, S. K., and Shum, P. (2017) Analysis of threshold cointegration with asymmetric adjustments in the Hong Kong grocery industry, Applied Economics, 49, 55915560.

Xu, J., and Hajek, B. (2013) The supermarket game, Stochastic Systems, 3, 405-441. 